RESEARCH PAPER

\title{
Effect of oil cake extract and organic manure on wilt of chickpea (Cicer areitinum L.) caused by Fusarium oxysporum f. sp. ciceri in vitro
}

\author{
Ashish Shrivastava \\ Department of Plant Pathology, College of Agriculture, Ganjbasoda (M.P.) India \\ (E-mail: ashishshrivastava1971@gmail.com)
}

\begin{abstract}
Studies were conducted to test the effect of oil cakes and organic manures on the growth of wilt pathogen under in vitro conditions. The extract of different oil cakes and organic manures were tested against $F$. oxysporum $\mathrm{f}$. sp. ciceri by poisoned food techniques in vitro. Least growth of pathogen was recorded in extracts of Neem cake showing excellent inhibitory effect of 70.87 percent reduction over control. Next best in order of mustard cake (65.36\%), linseed (62.99\%), groundnut (53.36\%) and least by other. Among the organic manures tested, vermi compost and FYM showed maximum growth inhibition of 35.95 and 30.62 percent over control, respectively.
\end{abstract}

Key Words : Chickpea, Fusarium oxysporum f. sp. ciceri, Wilt, Soil born fungi, Oil cakes, Organic manures

View Point Article : Shrivastava, Ashish (2021). Effect of oil cake extract and organic manure on wilt of chickpea (Cicer areitinum L.) caused by Fusarium oxysporum f. sp. ciceri in vitro. Internat. J. agric. Sci., 17 (2) : 146-148 DOI:10.15740/HAS/IJAS/17.2/146-148 Copyright@2021: Hind Agri-Horticultural Society.

Article History : Received : 21-02-2021 Revised : 26-02-2021 Accepted : 13.03 .2021 